Gut, 1972, 13, 441-449

\title{
Clinical, microbiological, and immunological studies in patients with immunoglobulin deficiencies and gastrointestinal disorders ${ }^{1}$
}

\author{
W. R. BROWN ${ }^{2}$, D. BUTTERFIELD, D. SAVAGE, AND T. TADA
}

From the Gastroenterology Division, University of Colorado Medical Center and Veterans Administration Hospital, Denver, Colorado, Children's Asthma Research Institute, Denver, Colorado, and the Department of Microbiology, University of Texas, Austin, Texas, USA

SUMMARY Seven patients with gastrointestinal disorders and deficiencies of serum and secretory immunoglobulins were evaluated clinically, microbiologically, and immunologically. Five patients had generalized deficiencies of immunoglobulins; two were selectively deficient. Diarrhoea and malabsorption in six of the seven patients were at least partially explained. Four of the five patients with generalized hypogammaglobulinaemia had intestinal infestation with Giardia lamblia; in three of the five, excessive numbers of anaerobic bacteria were cultured from small bowel fluids. Despite much variability in relative severity of patients' respiratory and gastrointestinal tract symptoms, deficiencies of mucosal immunocytes and immunoglobulins in nasopharyngeal and gastrointestinal tract tissues and secretions were similar. Except for one selectively IgA-deficient patient, all patients were deficient in IgE. The study characterizes in greater detail than heretofore the gastrointestinal disorders associated with immunoglobulin deficiency states.

Immunologically deficient patients commonly have gastrointestinal disorders, such as gluten-sensitive enteropathy (Crabbé and Heremans, 1967), nodular lymphoid hyperplasia (Hermans, Huizenga, Hoffman, Brown, and Markowitz, 1966), pernicious anaemia (Twomey, Jordan, Laughter, Meuwissen, and Good, 1970), parasitic or bacterial enteritis (McCarthy, Austad, and Read, 1965; Hoskins, Winawer, Broitman, Gottlieb, and Zamcheck, 1967), regional enteritis (Eggert, Wilson, and Good, 1969), amyloidosis (Conn and Quintiliani, 1966; Mawas, Sors, and Bernier, 1969), or disaccharidase deficiencies (Dubois, Roy, Fulginiti, Merrill, and Murray, 1970). The pathogenesis of these disorders is poorly understood, and many of their clinical, immunological, and microbiological features are incompletely characterized.

The immunoglobulin content of intestinal secre-

${ }^{1}$ This investigation was supported by Denver Veterans Administration Hospital training grant in gastroenterology TR 110; by a grant (FR-51) from the General Clinical Research Centers Program of the Division of Research Resources, National Institutes of Health; Denver Veterans Administration Hospital; NIH special fellowship 5 FO3 AM 38896-02; and USPHS research grant AI-08254-03.

'Address correspondence to: William R. Brown, MD, Veterans Administration Hospital, Department of Medicine (554/111E), 1055 Clermont Street, Denver, Colorado 80220, USA.

Received for publication 21 March 1972 . tions (Claman, Merrill, Peakman, and Robinson, 1970 ) and the distribution and immunoglobulin class of mucosal plasma cells (Crabbé and Heremans, 1967; Eidelman and Davis, 1968; Gelzayd, McCleery, Melnyk, and Kraft, 1971), especially IgE cells, have been evaluated infrequently in immunedeficient patients. Some authors have speculated that bacterial flora might be pathogenetic in the gastrointestinal abnormalities, but intestinal fluids have not been cultured often (McCarthy et al, 1965; Mawas et al, 1969; Gelzayd et al, 1971). Descriptions of the intestinal morphology and estimates of disaccharidase activities are also lacking from many reports.

Detailed studies of seven patients in this report further characterize gastrointestinal abnormalities associated with immunoglobulin deficiencies. Measurement of immunoglobulins and immunoglobulin-containing cells in respiratory and gastrointestinal secretions or tissues and culture of intestinal fluids by rigorously anaerobic methods were emphasized.

\section{Methods}

TESTS OF ABSORPTION AND GASTRIC ACIDITY The urinary excretion of D-xylose after a $25-\mathrm{g}$ dose 
(Roe and Rice, 1948), faecal fat excretion (van de Kamer, ten Bokkel Huinink, and Weyers, 1949), vitamin $\mathbf{B}_{12}$ absorption (Schilling, 1953), and activities of disaccharidases in jejunal biopsies (Dahlqvist, 1964) were estimated according to described methods. The $p \mathrm{H}$ of unstimulated gastric juice was tested in all subjects after fasting, and gastric acid secretion after betazole hydrochloride stimulation was measured in two patients.

\section{MICROBIOLOGICAL STUDIES}

During initial evaluation, duodenal fluid from each patient was cultured according to conventional aerobic and anaerobic techniques in the clinical laboratory. Subsequently, intestinal fluids from four of the patients were re-cultured, using rigorous microbiological techniques and selective media which have been described in detail (Savage and McAllister, 1971; Savage, Dubos, and Schaedler, 1968). Fluids were collected under $N_{2}$ from multiple sites of the small bowel via a sterile, double-lumen, polyvinyl tube. For anaerobic cultures, the fluids were serially diluted and plated onto pre-reduced media in an oxygen-free chamber, and then incubated in an atmosphere of $\mathrm{CO}_{2}$ and $\mathrm{H}_{2}$; for aerobic cultures, fluids were plated and incubated in air. Control fluids from 12 healthy, age-matched subjects were similarly studied. Stools and intestinal fluids were examined microscopically for parasites.

\section{BILE ACID STUDIES}

The concentrations of glycine and taurine conjugates of bile acids in duodenal fluids were estimated by thin-layer chromatography in silica gel (Abaurre, Gordon, Mann, and Kern, 1969). The relative concentrations of primary and secondary bile acids were estimated by gas-liquid chromatography of trifluoroacetate derivatives of methyl esters (Kuksis and Gordon, 1963).

\section{HISTOLOGY}

Biopsies were taken from the posterior nasopharynx under cocaine anaesthesia, from a rectal valve at the time of sigmoidoscopy, and from the stomach and duodenojejunal junction with a multipurpose tube (Brandborg, Rubin, and Quinton, 1959). All tissues were stained with haematoxylin and eosin for examination of morphology, and with methyl green pyronine for identification of plasma cells. Intestinal and rectal biopsies were stained also for amyloid with Congo red. Some intestinal biopsies were stained with Masson trichrome for identification of parasites.

IMMUNOLOGICAL METHODS

Concentrations of immunoglobulin $\mathrm{A}(\operatorname{Ig} \mathrm{A}), \operatorname{IgG}$, and $\operatorname{IgM}$ in serum were measured by a microimmunodiffusion method (Claman and Merrill, 1964), and in saliva by electroimmunodiffusion (Merrill, Hartley, and Claman, 1967) by D. Merrill. These immunoglobulins in duodenal fluid, nasal secretions, and sputum (concentrated five- to 10fold) were measured by radial immunodiffusion in agar containing rabbit $7 \mathrm{~S} \gamma$-globulin antibodies to human immunoglobulins (Brown, 1971; Newcomb and DeVald, 1969); reference antigens were 11S colostral IgA, serum IgG, or IgM. The fluids were tested for the free secretory component (SC) of exocrine IgA by double immunodiffusion, using rabbit antibodies specific for the secretory component of human colostral IgA (Brown, Newcomb, and Ishizaka, 1970). Serum IgE was measured radioimmunologically by K. Ishizaka (Ishizaka, Tomioka, and Ishizaka, 1970).

Immunoglobulin-containing cells and SC in tissues were identified by indirect immunofluorescence according to techniques, including tests of antibody specificity, which have been described (Tada and Ishizaka, 1970). Rabbit or guinea pig antibodies and goat anti-rabbit or anti-guinea pig antibodies conjugated to fluorescein isothiocyanate were applied.

Patients' delayed immunological responsiveness was evaluated in vivo by intradermal application of mumps, Candida, vaccinia, and trichophyton antigens and in vitro by measuring the ${ }^{3} \mathrm{H}$-thymidine uptake of circulating lymphocytes three days after stimulation with phytohemagglutinin.

Sera were tested for rheumatoid factor, antinuclear antibodies, and antithyroid antibodies in the clinical laboratory, and for antiparietal cell and anti-intrinsic factor antibodies by $\mathrm{Dr}$ K. Taylor. Serum agglutinating antibodies to Salmonella $\mathbf{H}$ and $\mathrm{O}$ antigens were measured before and two weeks after the subcutaneous injection of $0.5 \mathrm{ml}$ of $\mathrm{Sal}$ monella typhosa vaccine; measles and influenza $\mathrm{A}_{2}$ and $B$ antibodies were measured by microhaemagglutination inhibition; respiratory syncytial virus antibodies were measured by complement fixation.

The wheal-erythema reaction of patients' skin to intradermal injections of guinea-pig anti-IgE antibodies was tested as described (Newcomb and Ishizaka, 1969).

\section{Results}

The series (Table I) consists of five patients with generalized hypogammaglobulinaemia, presumably of the acquired variety, and two patients with selective deficiencies of immunoglobulins. Three patients had predominantly gastrointestinal symptoms, two had predominantly respiratory symptoms 


\begin{tabular}{llllll}
\hline Patient & Age & Sex & $\begin{array}{l}\text { Serum Immunoglobulin } \\
\text { Deficiencies }\end{array}$ & Gastrointestinal Problems & Respiratory or Other Problems \\
\hline H.E. & 61 & F & IgA, IgE & Gluten-sensitive sprue & Diabetes mellitus \\
P.W. & 17 & M & IgA, IgM, IgE & Mild diarrhoea & Rhinitis, allergic bronchitis \\
M.B. & 51 & M & IgG, IgA, IgM, IgE & Diarrhoea, malabsorption, pernicious anaemia & 'Asthma' in childhood \\
E.Y. & 64 & F & IgG, IgA, IgM, IgE & Diarrhoea, malabsorption, milk intolerance & Bronchiectasis \\
A.D. & 74 & F & IgG, IgA, IgM, IgE & Diarrhoea, malabsorption & Urinary tract infections \\
D.F. & 19 & M & IgG, IgA, IgM, IgE & Asymptomatic & Sinusitis, bronchiectasis, otitis \\
R.G. & 16 & M & IgG, IgA, IgM, IgE & Diarrhoea, malabsorption, milk intolerance & Pneumonia, sinusitis \\
\hline
\end{tabular}

Table I Clinical features of patients

\begin{tabular}{|c|c|c|c|c|c|c|c|}
\hline Patient & $\begin{array}{l}\text { Faecal } \\
\text { Fat }(g / 24 h r)\end{array}$ & $\begin{array}{l}\text { D-xylose } \\
\text { Excretion }(g / 5 \mathrm{hr})\end{array}$ & $\begin{array}{l}\text { Serum } \\
\text { Carotene } \\
(\mu \mathrm{g} / 100 \mathrm{ml})\end{array}$ & $\begin{array}{l}{ }^{57} \text { Co-B } B_{12} \text { Absorption } \\
(\% \text { excreted } / 24 \mathrm{hr})\end{array}$ & $\begin{array}{l}\text { Serum Calcium } \\
(\mathrm{mg} / 100 \mathrm{ml})\end{array}$ & $\begin{array}{l}\text { Prothrombin } \\
\text { Content }(\%)\end{array}$ & $\begin{array}{l}\text { Serum } \\
\text { Albumin }(\mathrm{g} / 100 \mathrm{ml})\end{array}$ \\
\hline $\begin{array}{l}\text { E.Y. } \\
\text { A.D. } \\
\text { D.F. } \\
\text { R.G. } \\
\text { Normal }\end{array}$ & $\begin{array}{l}4 \cdot 9 \\
12 \cdot 8 \\
11 \\
12\end{array}$ & $\begin{array}{l}2 \cdot 9 \\
2 \cdot 4 \\
4 \cdot 2 \\
5 \cdot 5\end{array}$ & $\begin{array}{l}48 \\
10 \\
36 \\
36\end{array}$ & $\begin{array}{c}3.7 \text { (IF) } \\
20 \\
3.9 \text { (IF) } \\
\text { N.D. }\end{array}$ & $\begin{array}{r}9.3 \\
3.9 \\
9.0 \\
\text { N.D. }\end{array}$ & $\begin{array}{c}88 \\
90 \\
100 \\
\text { N.D. }\end{array}$ & $\begin{array}{l}3 \cdot 0 \\
3 \cdot 2 \\
2 \cdot 6 \\
3 \cdot 0\end{array}$ \\
\hline values & $<5$ & $>4.5$ & $100-150$ & $7-15$ & $8 \cdot 8-10 \cdot 5$ & $>50$ & $3 \cdot 5 \cdot 5 \cdot 4$ \\
\hline
\end{tabular}

Table II Studies of intestinal absorption

${ }^{1}$ Radiolabelled vitamin $B_{12}$ administered with hog intrinsic factor.

'Increased to $8 \%$ after eradication of $G$. lamblia.

'Serum vitamin $B_{12}$ concentration normal $(520 \mu \mu \mathrm{g} / \mathrm{ml})$.

N.D. = Test not performed.

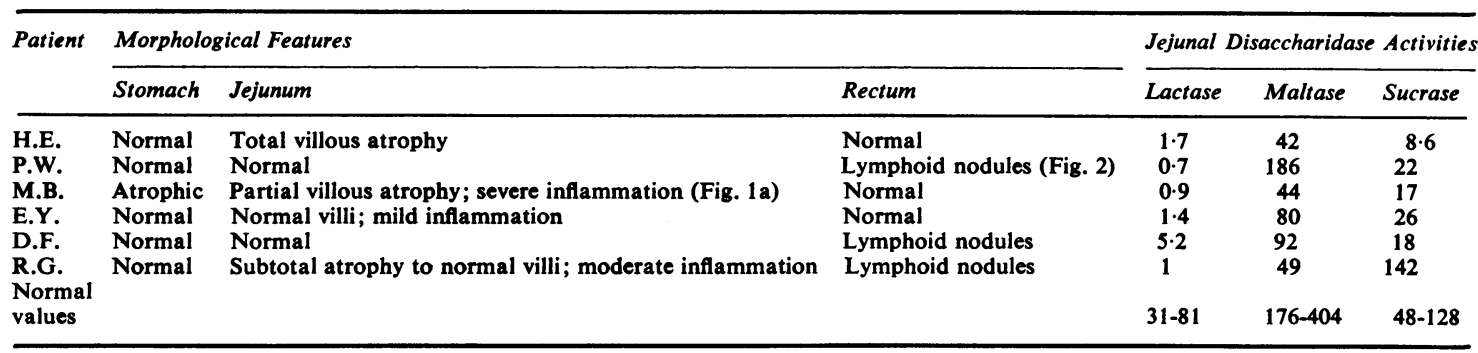

Table III Studies of gastrointestinal mucosae

${ }^{1}$ Micromoles of substrate hydrolyzed per minute per gram of protein.

and these symptoms were about equally severe in two (P.W. and R.G.). Milk-induced abdominal distension and diarrhoea were especially troublesome to E.Y. and R.G. Patients M.B., A.D., and E.Y. were severely debilitated and malnourished.

Chemical evidence of malabsorption was present in all patients except P.W. (Table II), but steatorrhoea when present was mild. A.D. was extremely hypokalaemic. Pernicious anaemia was documented in M.B. by gastric achlorhydria, gastric atrophy, and (after $\boldsymbol{G}$. lamblia were eradicated) correction of impaired ${ }^{57} \mathrm{Co}-\mathrm{B}_{12}$ absorption by administration of hog intrinsic factor. The $p \mathrm{H}$ of unstimulated gastric juice was more than 2 only in M.B. and R.G., who also failed to secrete measurable gastric acid after betazole hydrochloride stimulation.
Morphology of patients' intestinal mucosae (Table III, Fig. 1) varied greatly. Villi were of normal height in some biopsies, flat in others, and of variable height in multiple biopsies from some patients (A.D. and R.G.). Lymphocytic nodules were present in rectal or small bowel mucosae of three patients (Fig. 2). Amyloid was not demonstrated in any biopsy.

Disaccharidase activities (Table III) were reduced in the intestinal biopsies of all patients, including some in whom villi were histologically normal. Lactase deficiency in three patients was corroborated by 'flat' lactose tolerance tests.

Cysts or trophozoites of G. lamblia were found in stools, small bowel fluids, or jejunal epithelium of four of the five patients with generalized hypo- 


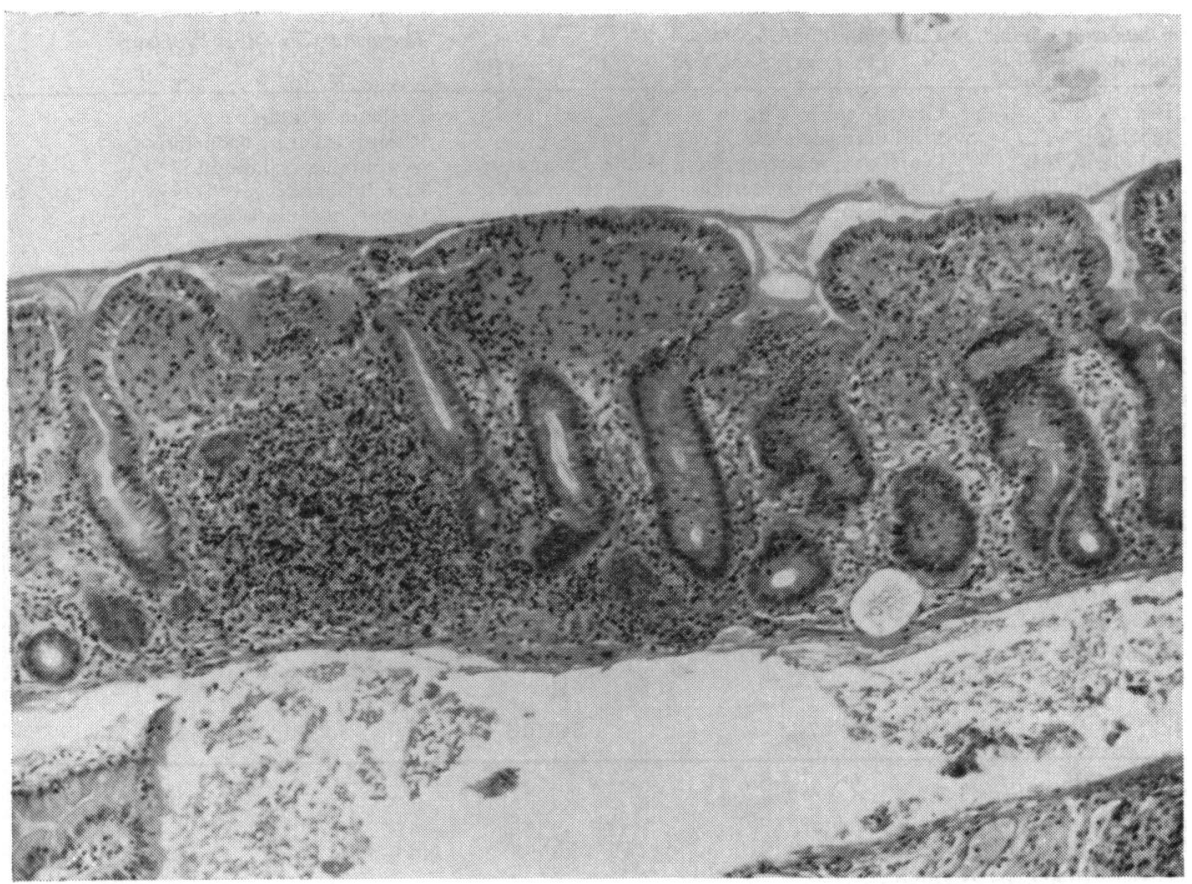

Fig. $1 M . B$.

Fig. 1a Jejunal biopsy, representative of multiple biopsies, before treatment for giardiasis. Villi are very short and blunt, and the lamina propria is densely infiltrated with chronic inflammatory cells. Plasma cells are absent $(\times 100$ haematoxylin and eosin).

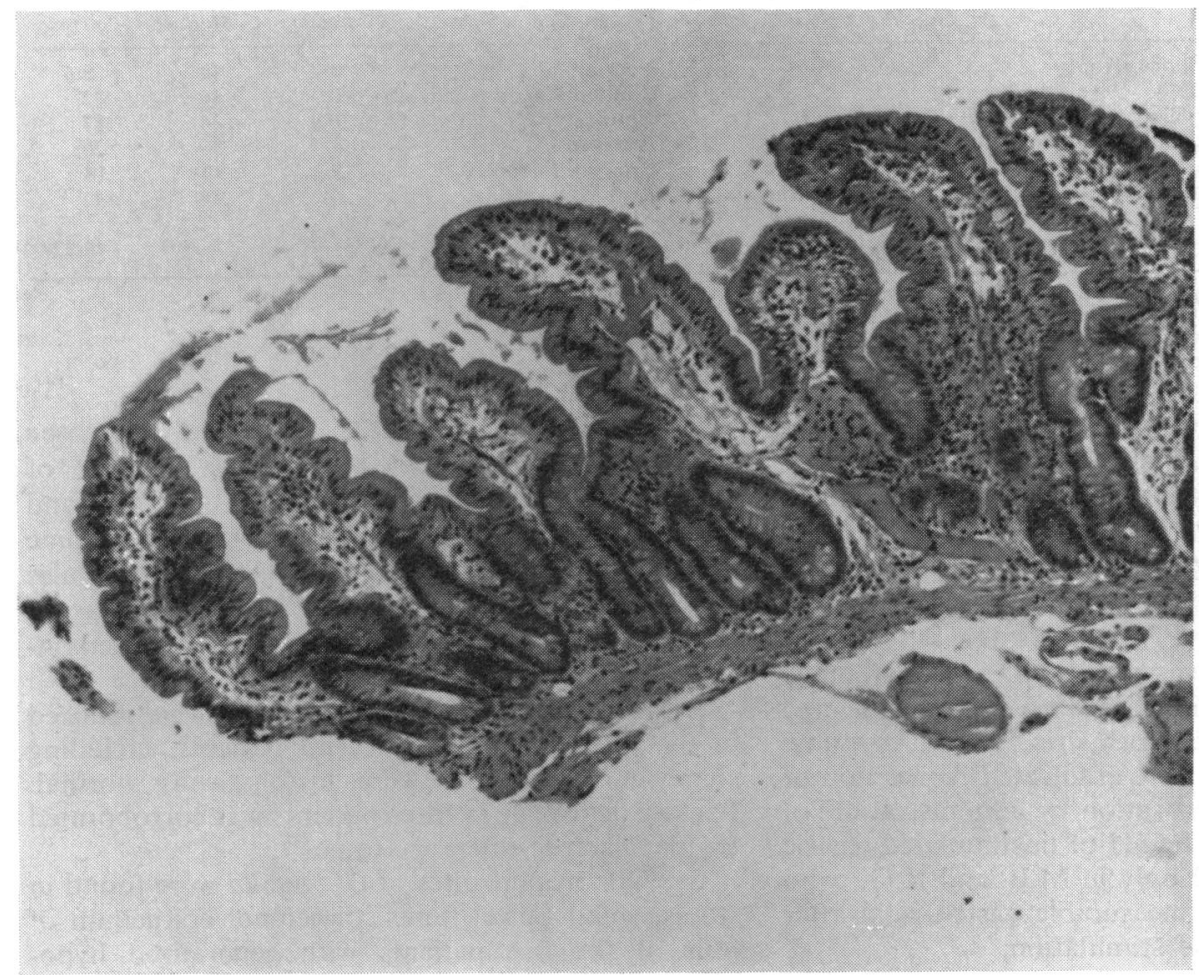

Fig. 1b Jejunal biopsy taken a few weeks after eradication of $\mathrm{G}$. lamblia. Villi, although somewhat shorter than normal, are much taller than in the pretreatment biopsy and inflammation is much less $(\times 100$ haematoxylin and eosin). 


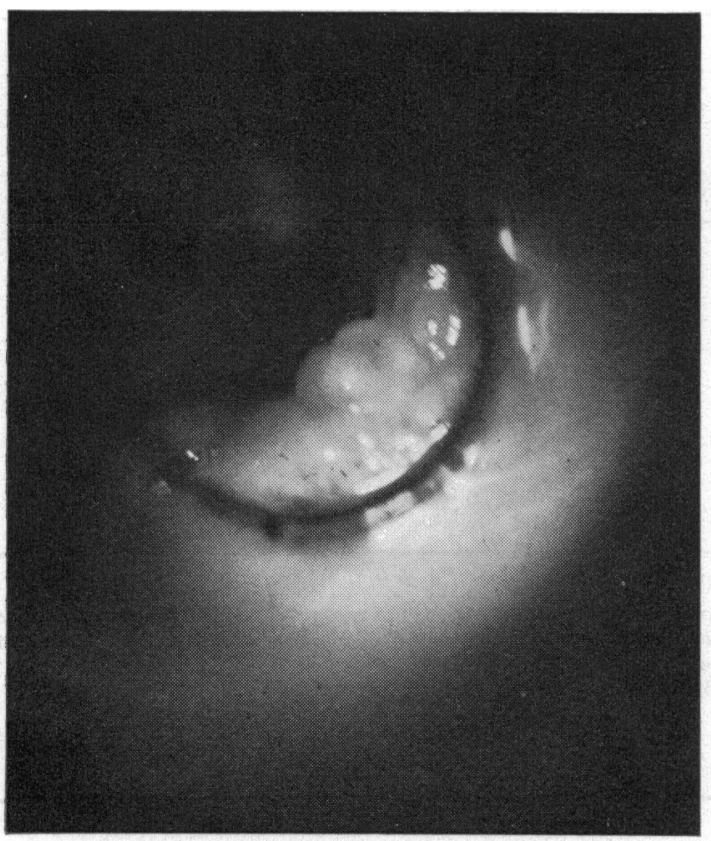

gammaglobulinaemia; they were not found in H.E. and P.W.

Cultures of patients' duodenal fluids by clinical laboratory techniques did not yield evidence of small bowel contamination with faecal organisms. In rigorously controlled anaerobic cultures, however, greater numbers of some anaerobic bacteria were cultured from fluids of three hypogammaglobulinaemic patients than from those of 12 control subjects (Table IV). The population of organisms was only slightly excessive in D.F., whose proximal bowel only was cultured, but were $10^{2}$ to $10^{7}$ organisms per millilitre greater than control values in some of M.B.'s and R.G.'s fluids. Aerobic bacteria were not excessively numerous in patients' fluids, except for a slight increase in those of M.B. The faecal flora of patients and control subjects were similar.

The ratios of glycine to taurine conjugates of bile acids in the duodenal fluids of two of the four patients studied (D.F. and H.E.) were normal or nearly normal (<5:1) (Abaurre et al, 1969), but were high $(9: 1,17: 1)$ in the two patients (M.B. and R.G.) with highest numbers of intestinal anaerobes. The proportions of bile acids that had been dehydroxylated to lithocholate and deoxycholate also were

Fig. 2a Sigmoidoscopic examination of rectum.

Fig. $2 P . W$.

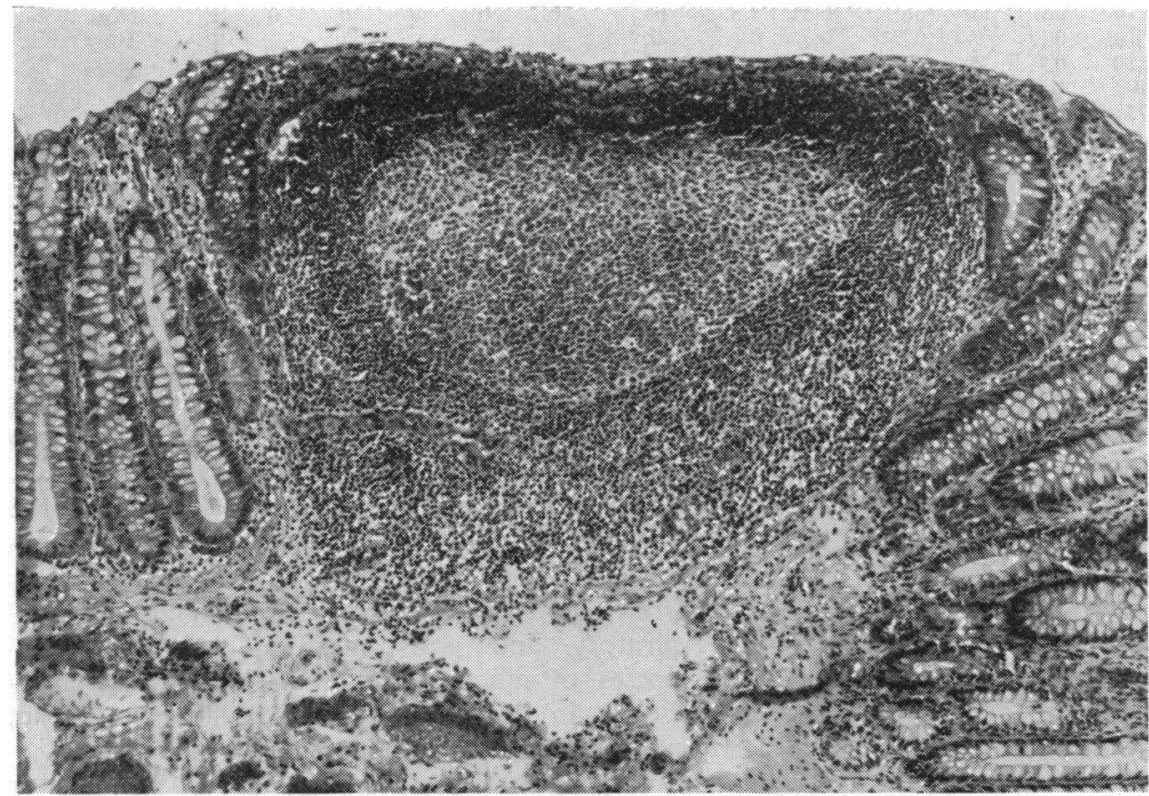

Fig. 2b Rectal lymphoid nodule with germinal centre ( $\times 90$ haematoxylin and eosin) Immunofluorescent stains demonstrated only a few IgG-containing cells in the nodule. 


\begin{tabular}{|c|c|c|c|c|c|c|c|c|c|c|c|c|c|c|c|c|c|}
\hline \multirow[t]{4}{*}{ Organism } & \multicolumn{17}{|c|}{ Site of Culture ${ }^{2}$} \\
\hline & \multicolumn{4}{|c|}{ Duodenum } & \multicolumn{4}{|l|}{2} & \multicolumn{3}{|l|}{3} & \multicolumn{3}{|l|}{4} & \multicolumn{3}{|l|}{5} \\
\hline & \multicolumn{17}{|c|}{ Patient } \\
\hline & H.E. & M.B. & B. R.G. & D.F. & H.E. & $M . E$ & B. R.G. & D.F. & H.E. & M.B. & R.G. & H.E. & M.B. & R.G. & H.E. & M.B. & R.G. \\
\hline Streptococci & 3 & 50 & $\begin{array}{c}6 \\
0(0-4)\end{array}$ & 5 & 0 & 5 & $\begin{array}{c}5 \\
0(0-5)\end{array}$ & 5 & $\mathbf{0}$ & $\begin{array}{l}0 \\
0(-5)\end{array}$ & 7 & - & $\overrightarrow{0(0-3)}$ & - & 6 & $\begin{array}{l}6 \\
0(0-9)\end{array}$ & 8 \\
\hline Bacteroides & $\mathbf{0}$ & $\begin{array}{ll}0 & 0\end{array}$ & $\begin{array}{c}5 \\
0(0-4)\end{array}$ & 0 & 4 & 4 & $\begin{array}{c}5 \\
0(0-5)\end{array}$ & $\mathbf{0}$ & $\mathbf{0}$ & $\begin{array}{l}0 \\
0(0-3)\end{array}$ & 7 & 一 & $\begin{array}{l}10 \\
0(0-5)\end{array}$ & 一 & 6 & $75(0-9)$ & 8 \\
\hline $\begin{array}{l}\text { Tapered rods } \\
\text { (fusiform bacteria) }\end{array}$ & - & $\begin{array}{ll}0 & \\
& 0\end{array}$ & $\begin{array}{c}4 \\
0(0-4)\end{array}$ & $\mathbf{0}$ & 0 & 0 & $0(0)$ & 3 & 0 & $\overline{o(0)}$ & 4 & - & $\begin{array}{l}0 \\
0(0)\end{array}$ & - & 0 & 0 & 0 \\
\hline Lactobacilli & 0 & $\begin{array}{ll}5 & 0\end{array}$ & $\begin{array}{c}0 \\
0(0-5)\end{array}$ & 5 & 4 & 0 & $\begin{array}{c}0 \\
0(0-5)\end{array}$ & 0 & 0 & $\overline{o(0-3)}$ & 0 & - & $\begin{array}{l}0 \\
0(0-5)\end{array}$ & - & 6 & $\begin{array}{l}6 \\
0(0-9)\end{array}$ & 8 \\
\hline Clostridia & - & ${ }^{0} 0$ & $\begin{array}{c}0 \\
0(0-4)\end{array}$ & 0 & 0 & 0 & $0(0)$ & $\mathbf{0}$ & 0 & $\overline{o(0)}$ & 0 & - & $\begin{array}{l}0 \\
0(0)\end{array}$ & - & $\mathbf{0}$ & $\begin{array}{l}6 \\
0(0-9)\end{array}$ & 0 \\
\hline Gram(-)cocci & - & $\begin{array}{ll}0 & \\
& 0\end{array}$ & $\begin{array}{c}0 \\
0(0-3)\end{array}$ & 5 & 4 & 4 & $\begin{array}{c}0 \\
0(0-5)\end{array}$ & 5 & 0 & $\begin{array}{c}0 \\
0(0-3)\end{array}$ & 0 & - & $\begin{array}{c}7 \\
0(0)\end{array}$ & - & 0 & $0(0-9)$ & 0 \\
\hline
\end{tabular}

Table IV Anaerobic bacteria cultured from intestinal fluids of four immunoglobulin-deficient patients ${ }^{1}$

${ }^{1}$ Data are recorded as the $\log _{10}$ of the number of organisms per millilitre of fluid. 0 indicates no organisms present at the level detectable by the microbiological techniques employed, ie, $10^{3}$ organisms per millilitre of fluid. The median and (range) of the $\log _{10}$ numbers of organisms cultured from fluids of 12 healthy control subjects is given below the patients' values.

${ }^{2}$ Samples were taken at $50-\mathrm{cm}$ intervals from the mid-duodenum to the distal ileum, site 5.

- No culture made.

\begin{tabular}{|c|c|c|c|c|c|c|c|c|c|c|c|c|c|c|c|c|c|}
\hline \multirow[t]{3}{*}{ Patient } & \multicolumn{10}{|c|}{ Immunoglobulin Concentrations } & \multirow{2}{*}{\multicolumn{6}{|c|}{$\begin{array}{l}\text { Immunofuorescent Cells in Digestive } \\
\text { Tract Mucosae }\end{array}$}} & \multirow{3}{*}{$\begin{array}{l}\text { Anti-IgE } \\
\text { Skin Test }{ }^{2}\end{array}$} \\
\hline & \multicolumn{4}{|l|}{ Serum } & \multicolumn{3}{|c|}{ Saliva } & \multicolumn{3}{|c|}{ Duodenal Fluid } & & & & & & & \\
\hline & $\begin{array}{l}\mathrm{Ig} G \\
(\mathrm{mg} / 10\end{array}$ & $\begin{array}{l}\operatorname{IgA} \\
00 \mathrm{ml})\end{array}$ & $I g M$ & $\begin{array}{l}\lg E \\
(\mathrm{ng} / \mathrm{m} l)\end{array}$ & $\begin{array}{l}I g G \\
(m g /\end{array}$ & $\begin{array}{c}I g A \\
(00 \mathrm{ml})\end{array}$ & $I g M$ & $\begin{array}{l}I g G \\
(m g / 1\end{array}$ & $\begin{array}{l}I g A \\
00 \mathrm{ml})\end{array}$ & $\operatorname{Ig} M$ & $I g G$ & $\operatorname{Ig} A$ & $\operatorname{Ig} M$ & $\operatorname{Ig} D$ & $\lg E$ & $S C$ & \\
\hline $\begin{array}{l}\text { H.E. } \\
\text { P.W. } \\
\text { M.B. }\end{array}$ & $\begin{array}{r}1130 \\
720 \\
119\end{array}$ & $\begin{array}{r}0 \\
<2 \\
8\end{array}$ & $\begin{array}{c}73^{2} \\
35 \\
9\end{array}$ & $\begin{array}{l}<10 \\
<10 \\
<10\end{array}$ & $\begin{array}{l}0 \\
0 \\
0\end{array}$ & $\begin{array}{r}0 \\
0 \\
10\end{array}$ & $\begin{array}{l}1 \cdot 5 \\
0 \\
0\end{array}$ & $\begin{array}{l}5 \\
1 \cdot 7 \\
2 \cdot 1\end{array}$ & $\begin{array}{l}0 \\
0 \\
5 \cdot 3\end{array}$ & $\begin{array}{l}\mathbf{0} \\
\mathbf{0} \\
\mathbf{0}\end{array}$ & $\begin{array}{l}0 \\
\pm \\
0\end{array}$ & $\begin{array}{l}\mathbf{0} \\
\mathbf{0} \\
\pm\end{array}$ & $\begin{array}{l}+++ \\
\pm \\
\mathbf{0} \\
\pm\end{array}$ & $\begin{array}{r}0 \\
\mathbf{0} \\
\mathbf{0}\end{array}$ & $\begin{array}{l}++ \\
\pm \\
0\end{array}$ & $\begin{array}{l}\mathbf{P} \\
\mathbf{P} \\
\mathbf{P}\end{array}$ & $\begin{array}{l}1.2 \times 10^{-4} \\
\mathrm{Neg} \\
1.2 \times 10^{-3}\end{array}$ \\
\hline $\begin{array}{l}\text { E.Y. } \\
\text { A.D. } \\
\text { D.F. } \\
\text { R.G. } \\
\text { Normal } \\
\text { values }\end{array}$ & $\begin{array}{r}129 \\
126 \\
93 \\
78 \\
720- \\
1400\end{array}$ & $\begin{array}{l}<6 \\
<2 \\
<6 \\
<3 \\
68- \\
314\end{array}$ & $\begin{aligned} & 16 \\
& 16 \\
&<7 \\
&<5 \\
& 93- \\
& 320\end{aligned}$ & $\begin{array}{r}15 \\
<10 \\
14 \\
<10 \\
20- \\
475\end{array}$ & $\begin{array}{l}0 \\
\text { nd } \\
0 \\
0 \\
0\end{array}$ & $\begin{array}{c}0 \\
\text { nd } \\
0 \\
0 \\
2-15\end{array}$ & $\begin{array}{l}0 \\
\text { nd } \\
0 \\
0 \\
0\end{array}$ & $\begin{array}{l}1 \\
0 \cdot 5 \\
0 \\
0 \\
0-10\end{array}$ & $\begin{array}{l}2 \\
1 \cdot 5 \\
0 \\
0 \\
3-44\end{array}$ & $\begin{array}{c}<7 \cdot 5 \\
0 \\
0 \\
0 \\
0- \\
32\end{array}$ & $\begin{array}{c}0 \\
0 \\
\pm \\
\text { nd } \\
\pm\end{array}$ & $\begin{array}{c}\mathbf{0} \\
\mathbf{0} \\
\pm \\
\mathbf{n d} \\
++ \\
++++\end{array}$ & $\begin{array}{c}+ \\
+++ \\
\mathbf{0} \\
\mathbf{n d} \\
+\mathbf{0}^{\sim} \\
+++\end{array}$ & $\begin{array}{c}0 \\
0 \\
\pm \\
\text { nd } \\
0^{\sim} \\
\pm\end{array}$ & $\begin{array}{c}\text { 0 } \\
\text { 0 } \\
\pm \\
\text { nd } \\
+\sim \\
++\end{array}$ & $\begin{array}{l}P \\
P \\
P \\
\text { nd } \\
P \\
\quad \text { or }\end{array}$ & $\begin{array}{l}\text { Neg } \\
\text { Neg } \\
1.2 \times 10^{-3} \\
\text { Neg } \\
1 \cdot 2 \times 10^{-4} \\
1.2 \times 10^{-5}\end{array}$ \\
\hline
\end{tabular}

Table V Immunological data

nd $=$ Test not performed

${ }^{1} \mathrm{SC}$, secretory component; $\mathrm{P}$, present in epithelial cells

Number of cells $/ 25 \mathrm{~mm}^{2}$ tissue: \pm occasional cell; +3 to 10 cells; ++10 to 30 cells; +++30 to $100 ;++++$ greater than 100 .

${ }^{2}$ Concentration of anti- $\gamma \mathrm{E}$ ( $\mathrm{ng}$ antibody nitrogen/ml) at which reaction occurred; neg, no reaction at $1.2 \times 10^{-2}$.

${ }^{3}$ H.E.'s mildly decreased IgM concentration became normal after dietary gluten restriction.

high (45\%) (Abaurre et al, 1969) in M.B., but were normal or only mildly elevated $(<25 \%)$ in the other three patients.

IgA was undetectable or in very low concentrations in saliva, duodenal fluid, sputum, and nasal washings of all patients, except in M.B., the only patient with measurable serum levels of IgA (Table V). Free secretory component was not demonstrated in the duodenal fluids of any patient or nine immunologically normal control subjects.

Immunofluorescent-positive mucosal cells were sparse or absent in all gastrointestinal and nasopharyngeal biopsies, except for increased numbers of IgM-containing cells in E.Y.'s jejunum, and normal or increased numbers of IgM and IgE cells in H.E.'s tissues (Table V; Fig. 3). Methyl green pyronine stains confirmed the immunocyte deficits. Secretory component was demonstrated in the epithelial cells of all gastrointestinal and nasopharyngeal biopsies (Fig. 4).

Irrespective of the relative severity of patients' respiratory and gastrointestinal symptoms, deficiencies of mucosal immunocytes and immunoglobulins in respiratory and gastrointestinal tract tissues and secretions were similar.

Cutaneous sensitivity to anti-IgE was absent or diminished in six patients, but normal in H.E. despite her low serum IgE level. 


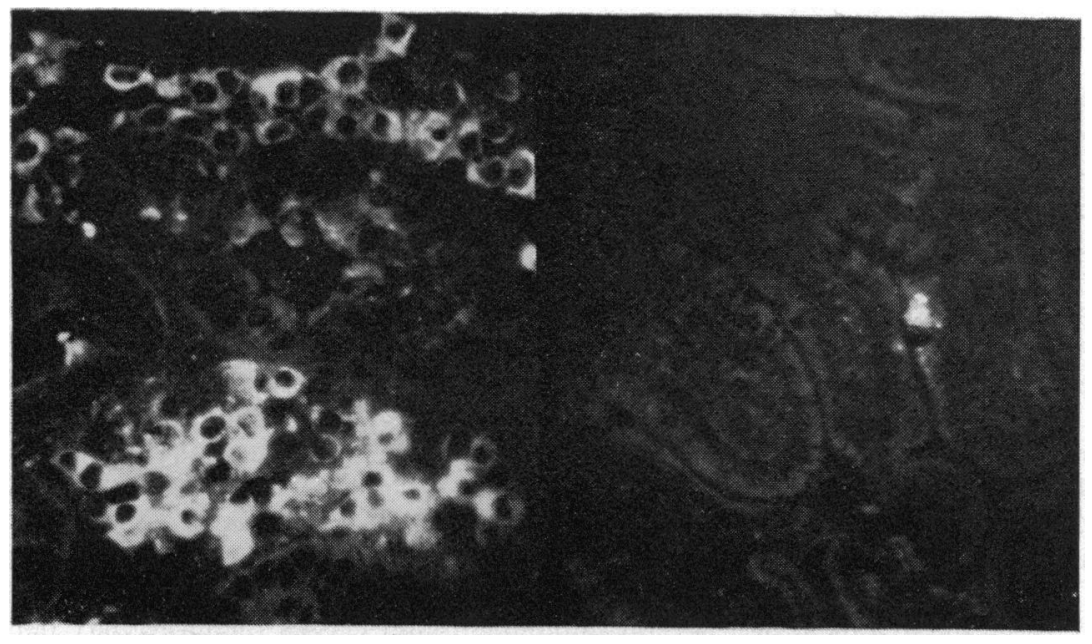

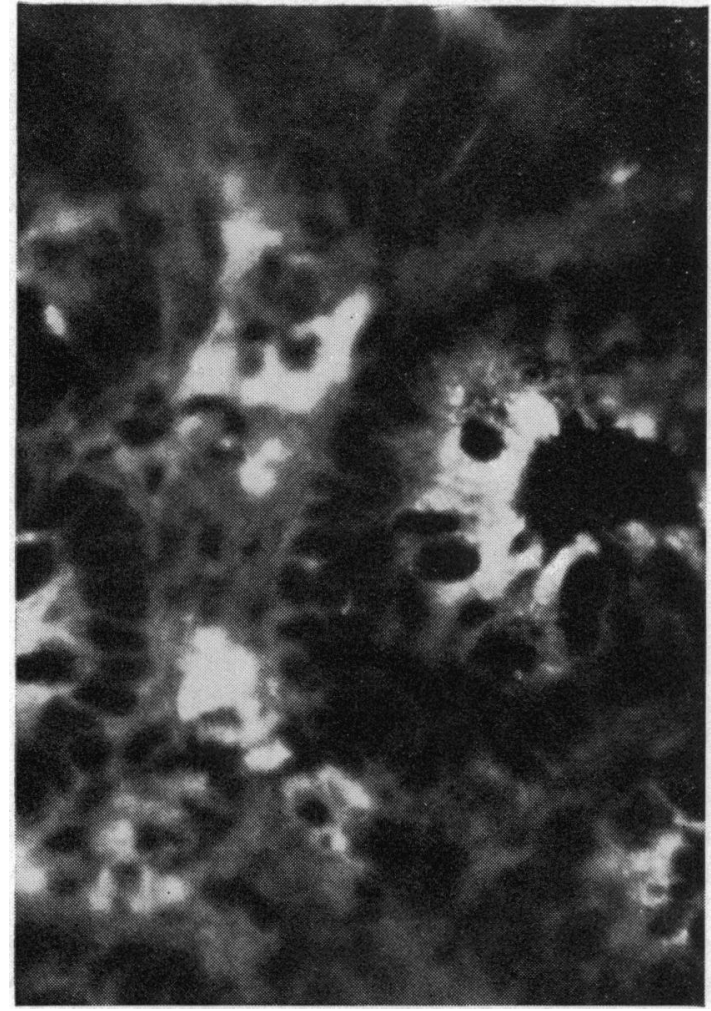

Fig. 3b Gastric biopsy stained with anti- $\gamma E$. The number of IgE cells is normal or slightly greater than normal.

Fig. 4 M.B.

Fig. 4a Immunofluorescent stain of jejunal biopsy demonstrating the secretory component (SC) of exocrine IIS Ig A in epithelial cells $(\times 125)$.

Fig. 4b Higher power view of intestinal epithelium stained with anti-secretory component $(\times 450)$.
Fig. 3 H.E.

Fig. 3a Jejunal biopsies from normal subject (left) and patient stained for IgA-containing cells $(\times 125)$.

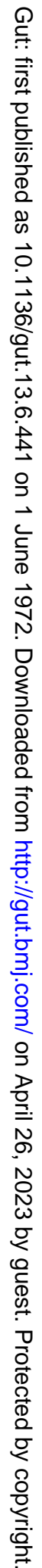

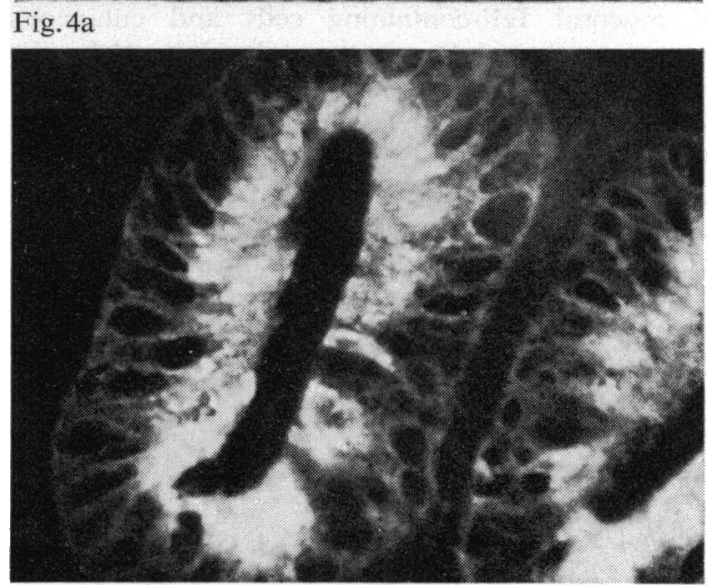

Fig. 4b 
Delayed cutaneous response to at least one of the four antigens applied was observed in each patient, and the lymphocyte response to phytohaemagglutinin stimulation was abnormally low in only one (E.Y.) of five patients tested. The tests for rheumatoid factor, antinuclear antibodies, antithyroid antibodies, antiparietal cell antibodies, and antiintrinsic factor were negative in six patients (R.G. was not tested). Serum titres of isohaemagglutinins and antibodies to influenza, measles, and respiratory syncytial virus were very low in the patients with generalized hypogammaglobulinaemia, but normal in H.E. and P.W. Patients M.B. and P.W. responded normally to typhoid immunization, but four other patients did not.

A gluten-free diet was effective in the treatment of H.E.'s enteropathy (Mann, Brown, and Kern, 1970), but was ineffective in all other patients. The four hypogammaglobulinaemic patients with giardiasis responded to eradication of the parasites (by atabrine, metronidazole, or furazolidone) with weight gain (88 to 140 pounds in M.B.) and disappearance or improvement of their diarrhoea and steatorrhoea. M.B.'s jejunal mucosa improved considerably after treatment (Fig. 1b). Whereas antiparasitic treatment was effective in M.B. and R.G., neither patient responded to broad-spectrum antibiotics, and M.B.'s symptoms were aggravated by cholestryamine and pancreatic enzyme supplements. A lactose-restricted diet was helpful in reducing diarrhoea and abdominal discomfort in R.G. and E.Y.

\section{Discussion}

The gastrointestinal abnormalities associated with immunological deficiencies are complex and variable. Comprehensive study of seven patients has helped to define more completely some aspects of the abnormalities.

Deficiency of IgE commonly accompanied deficits of other classes of immunoglobulins. The numbers of mucosal IgE-containing cells and cutaneous response to anti-IgE were normal only in H.E., the patient with selective IgA deficiency in whose serum IgE was not detected. Absence of detectable IgE from her serum is additional evidence that the biological activity of IgE may not be reflected in its serum concentration (Ishizaka, 1970). The significance of absence of IgE from the gut is not yet known. A mechanism by which it may participate in normal gastrointestinal immunological defences is the following. IgE is synthesized primarily by intestinal and other mucosal immunocytes (Tada and Ishizaka, 1970), and can sensitize intestinal mast cells (Tomioka and Ishizaka, 1971) to release vasomotor substances that could promote the entry of protective antibodies into the gut lumen (Murray, Jarrett, and Jennings, 1971). Whether IgE helps to protect the human gut from infestation with $G$. lamblia is unknown, but the suggestion has been made that it is protective against intestinal parasites (Rosenberg, Polmar, and Whalen, 1971).

This and other studies (Crabbé and Heremans, 1967; McCarthy et al, 1965) suggest that the severity of patients' gastrointestinal disorders is correlated with the severity of their immunoglobulin deficits. A deficiency of IgA alone is most often accompanied by mild malabsorption, whereas a generalized immunoglobulin deficiency more often results in severe, debilitating disease. Antibodies belonging to several immunoglobulin classes therefore may participate in immunological defences of the gut. The wide range of severity of respiratory and alimentary tract symptoms of patients with similar serum immunoglobulin abnormalities was not explained by this study.

The presence of secretory component in intestinal epithelial cells of IgA-deficient patients is evidence that the secretory component of exocrine IgA is synthesized independently of the heavy and light chains of the molecule (Tourville, Adler, Bienenstock, and Tomasi, 1969). The biological role of secretory component is unknown, although it might be responsible for the resistance of exocrine IgA to proteolysis (Brown et al, 1970). Its presence in damaged intestinal epithelial cells of immunoglobulin-deficient patients suggests that it does not play a major role in protecting the gut epithelium.

Rigorously anaerobic collection and culture of intestinal fluids revealed excessive numbers of anaerobic bacteria in the small bowels of some hypogammaglobulinaemic patients, suggesting that overgrowth with anaerobes may be common in such individuals. Except for a recent report (Hersh, Floch, Binder, Conn, Prizont, and Spiro, 1970), intestinal bacterial overgrowth has seldom been found in immune-deficient patients (McCarthy et al, 1965), but microbiological techniques employed in most studies probably were not sufficiently strict to permit growth of very oxygen-sensitive organisms (Savage et al, 1968). The pathological significance of increased numbers of intestinal anaerobes in hypogammaglobulinaemic patients is uncertain; patients of this series treated with antibiotics did not improve. High concentrations of glycine-conjugated or dehydroxylated bile acids in the small bowel fluids of the two patients (M.B., R.G.) with most severe bacterial overgrowth suggest that bacteria-induced alterations of bile acids could contribute to the diarrhoea and steatorrhoea. The failure of M.B. to respond to cholestyramine, however, does not 
support this possibility, although a similarly treated patient improved (Gleich and Hofmann, 1971).

$G$. lamblia infestation may contribute to the intestinal abnormalities of some hypogammaglobulinaemic patients, since patient M.B. and others (Hoskins et al, 1967) improved greatly after eradication of the organisms. The presence of G. lamblia in a patient without intestinal symptoms (D.F.) and their repeated recurrence in M.B. indicate that thorough search for the parasites should be conducted in immunoglobulin-deficient individuals.

This and another study (Dubois et al, 1970) have demonstrated that in immunoglobulin-deficient patients lactose intolerance may be a significant problem which can be improved by appropriate dietary restrictions. The previously reported finding (Dubois et al, 1970) of disaccharidase deficiencies in histologically normal jejunal mucosae of immunedeficient patients was confirmed in this study, but is still unexplained.

The authors are grateful to Dr Fred Kern, Jr, for performing the bile acid studies, and to $\mathrm{Dr} R$. Dubois, Dr L. Sides, Dr R. Krebs, and Dr M. Lee for referral of patients.

\section{References}

Abaurre, R., Gordon, S. G., Mann, J. G., and Kern, F., Jr. (1969). Fasting bile salt pool size and composition after ileal resection. Gastroenterology, 57, 679-688.

Brandborg, L. L., Rubin, G. E., and Quinton, W. E. (1969). A multipurpose instrument for suction biopsy of the esophagus, stomach, small bowel and colon. Gastroenterology, 37, 1-16.

Brown, W. R. (1967). Nonimmunoglobulin precipitin lines between intestinal fluids and antisera in immunodiffusion studies: an explanation for their occurrence and how they can be avoided. J. Lab. clin. Med., 77, 326-334.

Brown, W. R.. Newcomb, R. W., and Ishizaka, K. (1970). Proteolytic degradation of exocrine and serum immunoglobulins. J. clin. Invest., 49, 1374-1380.

Claman, H. N., and Merrill, D. A. (1964). Quantitative measurement of human gamma-2, beta-2A, and beta-2M serum immunoglobulins. J. Lab. clin. Med., 64, 685-693.

Claman, H. N., Merrill, D. A., Peakman, D., and Robinson, A. (1970). Isolated severe gamma A deficiency: immunoglobulin levels, clinical disorders, and chromosome studies. J. Lab. clin. Med., 75, 307-315.

Conn, H. O., and Quintiliana, R. (1966). Severe diarrhea controlled by gamma globulin in a patient with agammaglobulinemia, amyloidosis, and thymoma. Ann. intern. Med., 65, 528-541.

Crabbé, P. A., and Heremans, J. F. (1967). Selective IgA deficiency with steatorrhea. A new syndrome. Amer. J. Med., 42, 319-326.

Dahlqvist, A. (1964). Method for assay of intestinal disaccharidases. Analyt. Biochem., 7, 18-25.

Dubois, R. S., Roy, C. C., Fulginiti, V. A., Merrill, D. A., and Murray, R. L. (1970). Disaocharidase deficiency in children with immunologic deficits. J. Pediat., 76, 377-385.

Eggert, R. C., Wilson, I. D., and Good, R. A. (1969). Agammaglobulinemia and regional enteritis. Ann. intern. Med., 71, 581585.

Eidelman, S., and Davis, S. D. (1968). Immunoglobulin content of intestinal mucosal plasma cells in ataxia telangiectasia. Lancet, 1, 884-886.

Gelzayd, E. A., McCleery, J. L., Melnyk, C. S., and Kraft, S. C. (1971). Intestinal malabsorption and immunoglobulin deficiency. Arch. intern. Med., 127, 141-147.
Gleich, G. J., and Hofmann, A. F. (1971). Use of cholestyramine to control diarrhea associated with acquired hypogammaglobulinemia. Amer. J. Med., 51, 281-286.

Hermans, P. E., Huizenga, K. A., Hoffman, H. N., II, Brown, A. L., Jr., and Markowitz, H. (1966). Dysgammaglobulinemia associated with nodular lymphoid hyperplasia of the small intestine. Amer. J. Med., 40, 78-89.

Hersh, T., Floch, M. H., Binder, H. J., Conn, H. O., Prizont, R., and Spiro, H. M. (1970). Disturbance of the jejunal and colonic bacterial flora in immunoglobulin deficiencies. Amer. J. clin. Nutr., 23, 1595-1601.

Hoskins, L. C., Winawer, S. J., Broitman, S. A., Gottlieb, L. S., and Zamcheck, N. (1967). Clinical giardiasis and intestinal malabsorption. Gastroenterology, 53, 265-279.

Ishizaka, K. (1970). Human reaginic antibodies. Ann. Rev. Med., 21, 187-200.

Ishizaka, K., and Newcomb, R. W. (1970). Presence of $\gamma \mathrm{E}$ in nasal washings and sputum from asthmatic patients. J. Allergy, 46, 197-204.

Ishizaka, K., Tomioka, H., and Ishizaka, T. (1970). Mechanisms of passive sensitization I. Presence of IgE and IgG molecules on human leukocytes. J. Immunol., 105, 1459-1467.

van de Kamer, J. H., ten Bokkel Huinink, H., and Weyers, H. A. (1949). Rapid method for the determination of fat in feces. J. biol. Chem., 177, 347-355.

Kuksis, A., and Gordon, B. A. (1963). Quantitative gas-liquid chromatography of selected bile acid esters in SE-30, QF-1 and XE-60 silicone polymers. Canad. J. Biochem., 41, 1355-1366.

McCarthy, C. F., Austad, W. I., and Read, A. E. A. (1965). Hypogammaglobulinemia and steatorrhea. Amer. J. dig. Dis., 10, 945-957.

Mann, J. G., Brown, W. R., and Kern, F., Jr. (1970). The subtle and variable clinical expressions of gluten-induced enteropathy (adult celiac disease, nontropical sprue). Amer. J. Med., 48, 357-366.

Mawas, C., Sors, C., and Bernier, J. J. (1969). Amyloidosis associated with primary agammaglobulinemia, severe diarrhea and familial hypogammaglobulinemia. Amer. J. Med., 46, 624-634.

Merrill, D. A., Hartley, T. F., and Claman, H. N. (1967). Electroimmunodiffusion (EID): a simple, rapid method for quantitation of immunoglobulins in dilute biological fluids. J. Lab. clin. Med., 69, 151-159.

Murray, M., Jarrett, W. F. H., and Jennings, F. W. (1971). Mast cells and macromolecular leak in intestinal immunological reactions. Immunology, 21, 17-31.

Newcomb, R. W., and DeVald, B. (1969). Protein concentrations in sputa from asthmatic children: albumin, lactoferrin, $\gamma \mathrm{A}$ and rG. J. Lab. clin. Med., 73, 734-743.

Newcomb, R. W., and Ishizaka, K. (1969). Skin reactions to anti- $\gamma \mathrm{E}$ antibody in atopic, nonatopic, and immunologically deficient children and adults. J. Allergy, 43, 292-300.

Roe, J. A., and Rice, E. W. (1948). A photometric method for the determination of free pentoses in animal tissues. J. biol. Chem., 173, 507-512.

Rosenberg, E. B., Polmar, S. H., and Whalen, G. E. (1971). Increased circulating IgE in trichinosis. Ann. intern. Med., 75, 575-578.

Savage, D. C., Dubos, R., and Schaedler, R. W. (1968). The gastrointestinal epithelium and its autochthonous bacterial flora. J. exp. Med., 127, 67-76.

Savage, D. C., and McAllister, J. S. (1971). Cecal enlargement and microbial fiora in suckling mice given antibacterial drugs. Infect. Immunol., 3, 342-349.

Schilling, R. F. (1953). Intrinsic factor studies. II. The effect of gast ric juice on the urinary excretion of radioactivity after the oral administration of radioactive vitamin $\mathbf{B}_{12}$. J. Lab. clin. Med., 42, 860-866.

Tada, T., and Ishizaka, K. (1970). Distribution of $\gamma \mathrm{E}$-forming cells in lymphoid tissues of the human and monkey. J. Immunol., 104, 377-387.

Tomioka, H., and Ishizaka, K. (1971). Mechanisms of passive sensitization. II. Presence of receptors for IgE on monkey mast cells. J. Immunol., 107, 971-978.

Tourville, D. R., Adler, R. H., Bienenstock, J., and Tomasi, T. B., Jr. (1969). The human secretory immunoglobulin system: Immunohistological localization of $\gamma \mathbf{A}$, secretory 'piece' and lactoferrin in normal human tissues. J. exp. Med., 129, 411-430.

Twomey, J. J., Jordan, P. H., Jr. Laughter, A. H., Meuwissen, H. J. and Good, R. A. (1970). The gastric disorder in immunoglobulin-deficient patients. Ann. intern. Med., 72, $499-504$. 